IFAS Extension

\title{
Facts About Niacin ${ }^{1}$
}

\section{R. Elaine Turner and Wendy J. Dahl ${ }^{2}$}

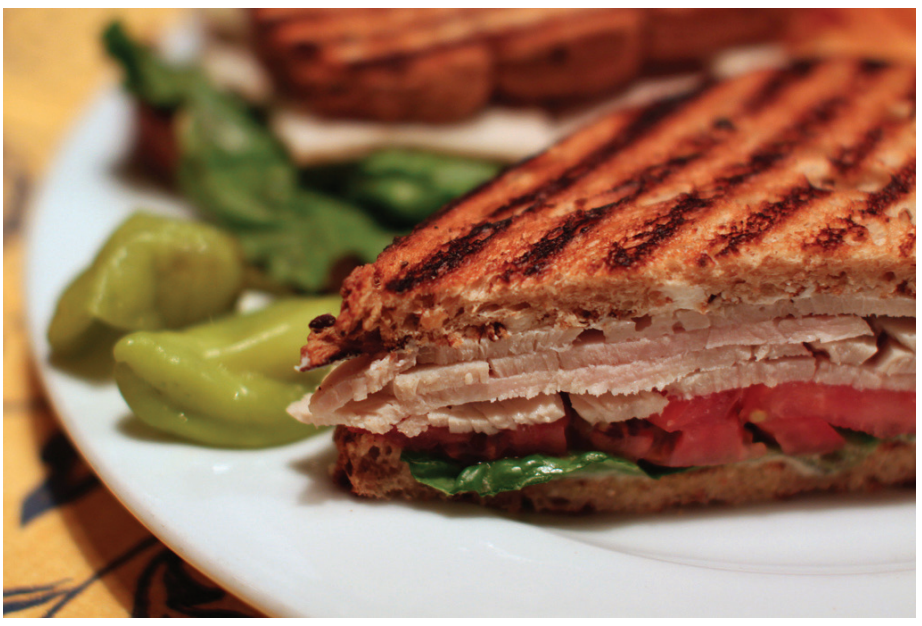

Figure 1. Grilled sandwich with turkey and whole-grain bread Credits: Mr. T in DC (CC BY-ND 2.0) http://flic.kr/p/6R5656

\section{Why do we need niacin?}

Niacin is one of the $\mathrm{B}$ vitamins (vitamin $\mathrm{B}_{3}$ ). Our bodies need niacin to use the energy in carbohydrates, fats, and proteins. Niacin also is needed for DNA repair and for the normal use of calcium in the body.

\section{What happens if we don't get enough niacin?}

The disease pellagra results from niacin deficiency. Pellagra was common in the 1800s when many poor Americans ate mostly corn, molasses, and salt pork which are poor sources of niacin. Because niacin is found in many foods we eat today, most people get plenty in their diets, and pellagra is now a thing of the past.
Pellagra could be called the " $\mathrm{D}$ " disease. It leads to diarrhea, dementia (memory disorder), dermatitis (skin rash), and death.

\section{How much niacin do we need?}

The following table lists recommended daily intakes of niacin:

Table 1. ${ }^{i}$

\begin{tabular}{|l|c|}
\hline \multicolumn{1}{|c|}{ Life Stage } & Niacin $(\mathrm{mg} /$ serving $)$ \\
\hline Men, ages 19+ & 16 \\
\hline Women, ages 19+ & 14 \\
\hline Pregnancy & 18 \\
\hline Breastfeeding & 17 \\
\hline mg = milligrams & \\
\hline
\end{tabular}

\section{How can we get enough niacin?}

Niacin is found in whole grain foods such as brown rice and whole wheat bread. If you don't choose whole grain foods, be sure to choose enriched foods. Niacin is one of four vitamins added to enriched grain products such as breakfast cereals and pasta. Look for the word "niacin" in the ingredient list to see if it has been added.

INGREDIENTS: Enriched flour (niacin, iron, thiamin mononitrate, riboflavin, folic acid), water, wheat fiber, baking powder...

1. This document is FCS8669, one of a series of the Department of Family, Youth and Community Sciences, Florida Cooperative Extension Service, Institute of Food and Agricultural Sciences, University of Florida. First published: June 2001. Revised: April 2006, May 2010. Reviewed with minor revision November 2012. Visit the EDIS website at http://edis.ifas.ufl.edu/.

2. R. Elaine Turner, PhD, RD, professor and associate dean, College of Agricultural and Life Sciences; Wendy J. Dahl, PhD, RD, assistant professor, Food Science and Human Nutrition Department; Institute of Food and Agricultural Sciences; University of Florida; Gainesville, FL 32611. 
Other good sources of niacin are peanuts, mushrooms, and seafood. Here are some foods and the amount of niacin they contain:

Table 2. ii

\begin{tabular}{|c|c|}
\hline Food & Niacin (mg/serving) \\
\hline Salmon, cooked, 3 oz & 7 \\
\hline Turkey, light meat, cooked, $3 \mathrm{oz}$ & 6 \\
\hline Ready-to-eat cereal, 1 cup & 5 \\
\hline Beef, lean ground, cooked, $3 \mathrm{oz}$ & 5 \\
\hline Peanut butter, 2 Tbsp & 4 \\
\hline Mushrooms, cooked, $1 / 2$ cup & 3 \\
\hline Spaghetti, enriched, cooked,1 cup & 2 \\
\hline
\end{tabular}

Did you know that....?

Tryptophan, one of the amino acids that make up protein, can be converted to niacin in the body. Tryptophan is found in all types of meats, and in milk, so these foods can be considered sources of niacin!

\section{How should foods be prepared to retain niacin?}

Because niacin is a water-soluble vitamin, it can be lost when foods are cooked in water. However, most good sources of niacin are not typically cooked in water. Cooking doesn't affect tryptophan content.

\section{What about supplements?}

Most people get plenty of niacin in their diet, so supplements usually are not needed. Most multivitamin supplements contain niacin. There is no need to take a supplement with more than $100 \%$ of the Daily Value for niacin.

\section{How much is too much?}

The suggested maximum niacin intake from supplements is $35 \mathrm{mg}$ a day for anyone over the age of 19 , and $30 \mathrm{mg}$ a day for anyone under the age of $19 .{ }^{i}$
Very high doses of niacin (1,300-3,000 mg per day) are sometimes used to treat high blood cholesterol levels. However, there can be side effects such as flushing of the skin, itching, nausea, increased blood glucose, stomach ulcers, and even liver damage. New forms of high-dose niacin supplements are extended release preparations to minimize these side effects. ${ }^{\text {iii }}$ Do not take large amounts of niacin unless prescribed by your doctor! Let your doctor know if you have side effects from taking niacin supplements.

\section{Where can I get more information?}

The Family and Consumer Sciences (FCS) agent at your county Extension office may have more written information and nutrition classes for you to attend. Also, a registered dietitian $(\mathrm{RD})$ can provide you with reliable information.

Reliable nutrition information may be found on the Internet at the following sites:

- http://fycs.ifas.ufl.edu

- http://www.eatright.org

- http://www.nutrition.gov

${ }^{i}$ Food and Nutrition Board. Dietary Reference Intakes for Thiamin, Riboflavin, Niacin, Vitamin B6, Folate, Vitamin B12, Pantothenic Acid, Biotin, and Choline. Washington, DC: National Academy Press, 1998, pp. 123-49.

ii U.S. Department of Agriculture, Agricultural Research Service. 2009. USDA National Nutrient Database for Standard Reference, Release 22. Nutrient Data Laboratory Home Page, http://www.ars.usda.gov/ba/bhnrc/ndl.

iii Gropper, S. \& Smith, J. (2008). Advanced nutrition and human metabolism ( $5^{\text {th }}$ ed). Mason, $\mathrm{OH}$ : Cengage Learning. 